\title{
A SECOND CHAPTER OF INDIAN HISTORY.
}

\author{
BY IDA M. STREET.
}

Since writing my first article for The ANnals, "A Chapter of Indian History" (January, 1899), I have come across a few more letters throwing light upon points spoken of there.

In regard to the Winnebago School, the subject of $\mathrm{my}$ previous paper, I find in the Miriam Edwards' Papers, that in June, 1827, Mr. Street visited Cumberland College, Princeton, Ky., in whose curriculum labor and study were combined. It was September 2, 1827, that he resigned his commission as Brigadier-General of militia to take the Indian Agency at Prairie du Chien. The idea of an industrial school of some sort, then was fresh in his mind when he went to take charge of the Winnebagoes.

Mr. William B. Street said that his father secured the appointment of Rev. David Lowry as principal of this school, and I have the impression though I have not the data to prove it, that Mr. Lowry was a graduate of Cumberland College. Althongh well prepared he does not seem to have been the best man for the place. He neither won the confidence of the Indians nor established a good manual training school. The buildings were there, and the Indians were there, but the school was not the success its well-wishers had hoped for. Among the family letters is one to William from his father, reproving him for calling $\mathrm{Mr}$. Lowry double-faced. William had been in the school under Mr. Lowry, and thought he knew him better than his father did. Indeed Mr. Street, although an honest and honorable man himself, was not a keen judge of human nature, and was liable to make mistakes in his choice of assistants.

The idea of an industrial school for Indians, however, did not become extinct because of this partial failure; for in 1838 Secretary of War Poinsett recommends in his report 
to Congress that a change be made in the manner of education among the Indians and that manual labor schools be establisbed to give them a knowledge of farming and the useful arts.

Not only did white men have to be convinced of the efficacy of schools for Indians, but the red men themselves had a contempt for them. Mr. A. W. Street says:

Many believed schools a scheme, as they looked upon missions, to rob the Indians. The Sacs and Foxes thought so. I remember at the attempted treaty of 1842 , that Keokuk in a speech to Hartley Crawford, Commissioner of Indian Affairs, said, with a concentrated bitterness I have never seen equalled, in answer to a proposition for a school"Kitche-Waleshi-very, very bad." But no English words can convey the indignant, bitter scorn and hatred he threw into the words.

When Mr. Street was removed to the Des Moines River Agency of the Sacs and Foxes, he did not attempt the establishment of another school. Yet he had not given up the idea of industrial training, for in the treaty signed at Washington in the fall of 1837 , he paid especial attention to the provisions for a model farm.

The Winnebagoes and the Sacs and Foxes both signed treaties at Washington that fall; one, October 31, and the other November 1. Whether Agent Street, who had just been removed from the Agency of the Winnebagoes had anything to do with the wording of their treaty, we cannot say; but it is certain that in main points they were similar.

One hundred thonsand dollars was set aside to pay the debts of the Indians. For the purpose of settling the claims. of the creditors-usually traders-a commission was appointed to go to the Indian country and adjust these claims. The alleged fraud of the Winnebago commissioners for their treaty of 1837 will be taken up later. The Sac and Fox commissioner, according to a letter of Henry Dodge, Governor of Wisconsin, and Superintendent of Indian Affairs in the territory, was Mr. Fleming, although others mention Maj. Hitchcock in this connection. Mr. Fleming appointed Rock Island as the place for the creditors to meet and have 
their claims adjusted. Mr. Street very reluctantly consented to this. (See Correspondence of Gen. Street. Gov. Dodge's letter of December 10, 1838). We find no complaint of the findings of this Commission.

In these treaties were also grants of several thousand dollars to the families of sub-agents, interpreters and others. Boilvin, one of the witnesses to the Winnebago treaty, receives in it a grant of twenty thousand dollars for services rendered. This is not a settlement of his account presented to the commissioners later.

The balance of the money is to be invested for the Indians at five per cent, and the interest paid them yearly; a part to be paid in money, a part in goods, and a small part for schools.

The differences in the two treaties signed in the fall of 1837 lies in such details in the Sac and Fox treaty as $\$ 28$,000 to be paid in goods at cost; $\$ 10,000$ for the erection and support of two mills and millers for five years; $\$ 24,000$ for breaking ground, and $\$ 2,000$ for laborers. These provisions were for the encouragement of the Sacs and Foxes in farming. If they could once be helped to make a start they might learn to farm the white man's way; but the undertaking seemed to them too formidable for their unaid. ed efforts. There was also a clause providing $\$ 10,000$ for food for two years until the Indians could get their farms started. This latter clause was not at once carried out as shown by Agent Street's report in 1838.

The Winnebagoes' allowance for a mill was $\$ 3,000$, for breaking ground $\$ 10,000$, and for provisions the same, $\$ 10,000$. Out of their interest $\$ 3,200$ is to be paid for the school.

Agent Street says in his report of 1838, after describing the country retained by the Sacs and Foxes after the treaty of 1837 as about 140 miles square, Raccoon Forks being about 50 miles interior: 
It would be difficult to say how these Indians are employed, whether in the chase or in farming. Since their return from Washington last November, the whole of the two tribes have done little else than live upon the presents of horses, etc. given them, drink whiskey, and live among the white settlers on their borders and in their country; for grent numbers of the whites are settled in the Indian country and going in and out continually. Notwithstanding this, the squaws have raised great quantities of corn, beans and pumpkins.

The Foxes have spent about 250 acres in cultivation and raised about 7,500 bushels of corn.

The Sacs have 260 acres in cultivation and raised about 6,000 bushels of corn, besides beans and pumpkins.

The Foxes have during the summer hunted and killed some game to eat; the Sacs have not attempted to hunt, the country in their immediate vicinity being very destitute of game; and at one time in June, July and August, I thought the whole tribe would perish for provisions before the corn would arrive at a situation to be used. This state of the nation is traceable to two causes: first, the treaty provision for $\$ 5,000$ worth of provisions to be given them for two years being (to them unexpectedly) withheld; and second, the dispensing among the chiefs and braves of large quantities of intoxicating drinks by the small dealers and border settlers, which later came in shoals with accounts to the payment of annuities, on the 8 th instant, and have large claims to be presented to the commission on the treaty stipulations of 1837 (setting apart $\$ 100,000$ to pay claims). In order to curry favor and keep up an influence with the Indians, all this year great quantities of whiskey have been freely dispensed to the Sacs and Foxes, beyond anything that has occurred since my first acquaintance with them in 1834; and although $I$ have under the instructions of the Commissioners of Indian Affairs, located their agency among them within their own country, and within an hour's ride of their principal town, I have little hope that any good can be done the Indian unless some more efficient plan can be adopted to exclude whiskey and the white people from the Indian country.

At the late payment of annuities, in their own country, there were not less than 100 white men in attendance, and perfectly excluded the Indians from the house the money was to be paid in (a new hewn-log house, unfinished, intended for a council-house) until I several times requested them to retire, to permit the Indians to come in and receive their money. They went out, but took out all the chinking between the logs to look in and see what was going on. After the payment, the Indians paid to these small dealers, whiskey sellers, etc., something over $\$ 12,000$ in specie, and the Foxes took $\$ 3,000$ to pay the claimants, they said, not there. I mention these facts to show the Department the absolute necessity of the exclusion of the whites, except licensed traders, for the Sac and Fox coun-. try; and in relation to these $I$ would add, that the only hope I can entertain of a benefit to the Indians is in the exclusion of all white men, but one trader, from the Indian country, whose goods and prices should be 
controlled by the United States agent, or that the United States take the trade into their own hands and exclude all traders, etc.

Under the Instructions of the Commissioner of Indian Affairs, the building of two saw and grist mills, and the breaking and fencing of 1,439 acres of prairie land, have been let to the lowest bidder, and in process of completion. The ground will, from all appearances, be ready for cultivation in the spring, and the mills during the ensuing summer and fall; 640 acres of the land is on the Iowa and 799 on the Des Moines; which will put it in the power of the Sacs and Foxes to put in large crops of corn, etc., the ensuing year, upon land well broke and fenced from the inroads of stock. But, unless the whites are prevented from taking whiskey into their country, little benefit can arise to the Indians from all that has been done, or now is doing, for their improvement by the United States.

A promise is made in the treaty of 21 st October, for the expenditure of $\$ 2,000$ per annum, for five years, in support of a farm in the Sac and Fox country; and by former treaties and appropriations, $\$ 800$ per annum, to aid them in farming, the purchase of agricultural instruments, domestic animals, etc.; under the exclusion of whiskey and white persons not authorized to go into the Indian country, these provisions might be made of great use to the Indians, if early carried into effect at a point near the Indian towns, where the several improvements in farming, getting and saving grain, hay, etc., could be closely observed by the Indians, and the raising and taking care of hogs, cattle, and horses more immediately seen in their own country.

No part of the appropriation for the purchase of domestic animals, implements of husbandry, etc., and of the $\$ 2,000$ per annum for agricultural purposes, has yet been used, though $\$ 60$ was appropriated before $1836 ; \$ 740$ in $1836, \$ 800$ in 1837 , and $\$ 2,000$ in 1837 ; making appropriations now made to the amount of $\$ 3,600$ for those purposes. If, with the appropriations to be made for this year, these sums are directed to be expended for the purposes designed, and measures taken to exclude the whites and their whiskey from the country of the Sacs and Foxes, I believe that a great improvement npon the manners and habits of the Sacs and Foxes may be made. (Ex. Doc. 25th Cong. 3d Sess. 1838-9, p. 465).

This description of the greed of the traders explains a sentence in Maj. Sanford's letter of March 13, 1839 (?). "The Secretary will furnish you troops to keep off the rabble at the next payment, if you so desire it."

The suffering of the Sacs and Foxes in the summer of 1838 was evidently relieved by an order from Maj. Hitchcock, distributing agent for the Secretary of War at St. .Louis; for in a letter dated August, 1838, he says: 
I write in great haste to acknowledge the receipt of your requisitions for the suffering Sacs and Foxes and to say that the Ariel will leave provisions at Phelps and at Warsaw for you.

Please make the best terms in your power for its transportation to the points of delivery in the nation and draw on me at the foot of the accounts for payment in the usual way. I have sent 179 barrels of flour to Warsaw and 88 to Phelps and 8 and 16 barrels of pork (24 altogether) the 16 to Warsaw.

Gen. J. M. STreet, Very respectfully, Yo. obt. serv,

Prairie du Chien.

E. A. Hitohoook Maj Dis Ag.

In his report of 1838 Agent Street advocates the exclusion of all traders but one, whose goods and whose prices shall be controlled by the United States agent. A similar provision had been made for the Sacs and Foxes in the treaty of 1804 "in order to stop the abuses and impositions which are practiced upon the said tribes by the private traders." But in the treaty of 1822 made through their agent Thomas Forsyth, they release the United States from all obligations to supply them througb one trader or factor.

As far as treaty stipulations are concerned the Sacs and Foxes had been better cared for than the Winnebagoes up to 1832 . By the treaty of 1804 the Sac and Fox Indians. were to be paid in goods. In the treaty of August 4, 1824, the United States engage to provide and support a blacksmith for the Sac and Fox Nation, "so long as the President of: the United States may think proper, and to furnish the said. nations with such farming utensils and cattle, and to employ such persons to aid them in their agriculture, as the President may deem expedient."

Article 5. The Annuities stipulated to be paid by Article 3, are to be paid either in money, merchandise or provisions, or domestic animals, at the option of the aforesaid tribes, and when said annuities or part thereof are paid in merchandise, it is to be delivered to them at the first cost of the goods at St. Louis free from cost of transportation.

This treaty, better in its provisions than that of 1822 , is signed as principal witness by Lawrence Taliaferro, Indian

Vot. VI-24. 
Agent at St. Peters. His Agency was afterwards restricted to the Sioux.

The trouble, though, was not so much with the making of Indian treaties as with the execution of them. The small trader and the American Fur Co., often combined to frustrate all efforts to better the condition of the Indian. Not only did the company make a great deal of money out of the valuable pelts they got of the Indians for a small price; but they put in claims at every treaty for thousands of dollars said to be due them from the Indians. Unlimited credit is a bad thing for any one and especially for a savage who has no idea of money values. And unlimited credit is what the poor Indian thought he had with this wealthy American government which was so ready to buy his lands of him.

With this understanding of the Indian trade, we do not wonder that the American Fur Co. made a desperate attempt to control not only the trade, but the Indian agents themselves. They were determined to drive out of the Indian country all disinterested agents who had the real good of the red men at heart.

There was little doubt in the mind of Agent Street and his intimate friends that the action of the War Department in ordering him so frequently to Rock Island and the law passed by Congress at the close of the session of ' 33.4 mak. ing Prairie du Chien a sub-agency and ordering Mr. Street to reside at Rock Island was done at the instigation of the American Fur Co. Their object of course, was to remore him from influence over the Winnebagoes. Mr. Street was in Washington in that winter, as stated above, and probably learned more there of the plotting against him than he could have done at home. Unfortunately no important letters* of this year can now be found in the family. My statement here is, therefore, based on what I have heard William B. Street, say about the matter.

\footnotetext{
-One lotter of August 26, 1833, has beon found but that is reserved for another article.
} 
It will be seen from what has been given that Agent Street's life was a constant struggle against the efforts made by unscrupulous persons to defraud and demoralize the Indian. He was by nature hot-tempered and impulsive, he was not, perhaps, at all times as discreet as he might have been, especially in the first few years at Prairie du Chien; but every one who came into personal relations with him was convinced as to his sincerity and great desire to benefit his wards; he looked upon them as helpless, wayward chil. dren put into his care. The conviction of his sincerity was undoubtedly what made such men as Col. Zachary Taylor and Maj. Ethan Allen Hitchcock his devoted friends; and had made such men as Henry. Clay and Andrew Jackson his personal as well as political well-wishers.

The first time that Agent Street seems to have aroused the wrath of the American Fur Co. was in the treaty of September, 1832, when he secured the Winnebago School, as I told in my first article. Perhaps one direct result of this action was shown in the following persecution and prosecution.

In April, 1833, and again in the winter of 1833-4 he had been called to Washington to answer charges against Major Kearney and himself. Under Agent Street's orders, who acted under advice from Gen. Clark* at St. Louis, Major Kearney had had a white man arrested for stealing timber from the Indian lands above the Portage and had seized the timber. The white man had brought suit for illegal arrest, alleging that Maj. Kearney's orders were not properly worded. In this case Mr. Street paid considerable in costs and lawyers' fees, and he appealed to the government for money to reimburse him for his loss. Not only was this refused, but the agents of the American Fur Co., as Mr. Street firmly believed, secretly complained of him to the War Depart. ment as being an officious meddler in other people's affairs. At any rate he was called to Washington in '33-4 to explain

*Of the Lewis and Clark expedition. 
his action in this case. This is referred to by Rev. Mr. Brunson of Prairie du Chien in his article on Mr. Burnett, sub-agent under Mr. Street. (Wis. Hist. Soc. Proceedings, Vol. 1.)

On March 26, 1835, Mr. Hercules Dousman, Agent for the American Fur Co., at Prairie du Chien, made complaint to the Commissioner of Indian Affairs that Mr. Street was neglecting his duty at Prairie du Chien in allowing the blacksmith to do work for others than Indians. September 11 of the same year, Secretary of War Elbert Herring writes to Gen. Clark, Superintendent of Indian Affairs at St. Louis, as follows:

I have received your letter of the 27th ult, enclosing that of Col. Taylor in relation to the charge made by Mr. Dousman against Gen. Street for neglect of daty respecting the blacksmith shops for the Winnebagoes. Your statement and that of Col. Taylor vindicate the official conduct of Gen. Street and furnish strong reason to believe the accusation brought against him altogether unjust and unfounded.

Another quality, besides his honesty, which kept Mr. Street continually in hot water, was his pugnacity. When he once entered into a contest he could not give up until he had fought it out to the bitter end. He had shown this before he ever came to the Indian country in his attempts to. uncover the Aaron Burr conspiracy in Kentucky. In that controversy he was referred to as "the fighting editor of the Western World." It was then that he received the wound which for some time after disabled him from steady office. work and rendered a position that required outdoor activity, a necessity.

Yet there were some bright spots in the life of this fighter for the Indians' rights. In the summer of 1839 he writes to his son in regard to the new agency on the Des. Moines river.

I feel very comfortably and well fixed having a large field of 160 acres. broken and fenced and about 100 acres of it in oats, peas, corn and potatoes, and the balance planted on shares. A garden field broke and planted and the yard paled and a lot of 5 or 6 acres, well fenced, around $\mathrm{my}$ 
stable, with a stake-rider fence about 8 feet high with a large gate, on iron hinges, of carved rails and large posts. My garden also has a good gate on iron hinges and a steel spring latch, and the field two large gates of similar construction. I enter into this detail to show you and Mary that after all our trouble of the double move* we are again quite comfortable and are pleased with our new home.

Although the agency house was to have been done in the fall, in May, they found it still incomplete. He says in this same letter:

I left your mother and all the family well and we have got into our new house and somewhat comfortably established once more. I am even surprised to see with what ease your dear mother accommodates herself to difficulties, for in removing and finding our house unfinished we of course had to encounter many new and to her untried difficulties, yet she has mastered them. The house is nearly completed and the contractor and all his hands, except one (the painter) gone over to the Indian town to work on his contract there. And even the painting is all done on the inside of the house except the two halls and the staircase above and below and I directed them to be painted while Alexander and myself are on this trip when your mother will move into the four rooms on the first floor, which can all be used through the back piazza without going into the passage at all. I hope they will be done by the 20th of this month.

$\mathrm{He}$ says in another letter written when he first explored the country on the Des Moines river:

I shall not attempt to say how much we are pleased with the country. Excepting the absence of springs there is little else in a natural point of view to ask. Like all new and rapidly settling countries the people live in indifferent houses and are in want of almost every necessary. This renders traveling in the country unpleasant.

Although Mr. Street was so loth to leave Prairie du Chien, he had found some conditions in Rock Island much better. For one thing the trader, Col. Davenport, was a more honorable man than those in Prairie du Chien. $\mathrm{He}$ says in a letter to Mr. Lowry written from there in $\mathbf{1 8 3 6 \text { : }}$

These Indians are vastly different from the Winnebagoes-greatly superior in every respect-and have a trader of more liberal and extensive views than the Winnebagoes, but these views all tend to his own pecuniary interest, still his enmity to God will render it difficult to christianize the

*By double move he means the removal of part of his goods from the officers' quarters, Rock Island, where he had been staying, and the remainder from his former home in Prairie du Chien where his family had been. 
Indian in his life-time. (Yet) He won't sell them liquor except in the interior of their country and then sparingly. He does all in his power to prevent drinking among the Indians-and he won't keep it at his own store to sell. What he has is in his house and occasionally he will give them one or two drinks. No temperance agent could be more urgent to them. This he explains is to his interest-if they drink they lose their blankets, guns, traps, and health, and frequently their lives. This is a dead loss to him. A naked Indian with no gun or traps can't be expected to hunt to any advantage, and his state of health also renders him listless and inactive. If he dies, all he had got is lost and the profits on the furs of a good hunter. Every year amongat drinking Indians sees a large loss by death of the best hunters and a failure to pay by naked hunters who sold their blankets and guns for drink. By selling goods of a superior quality at a moderate profit he secures the confidence of the Indians. The company who supply him know that once a year in the summer he will get $\$ 27,000$ in cash, . . . and they are glad to sell him low all he wants. He knows the moment the agent hands the money to the Indians he will get the whole $\$ 27,000$ handed over to him and he, to secure it deals so fairly and liberally and is so kind to them in all his intercourse they see he is their friend and will deal nowhere else. A few small accounts are made in the year, at a distance, by some Indians-those he pays, taking occasion to show them by the accounts how much cheaper he will sell them the same articles of better quality. By this course of conduct, he has gained an unbounded influence over the Indians and they will not lightly act differently from his wishes. All this is from self interested motives and yet the Indians are benefitted.

From this description we can understand why. in his report to the War Department two years later, Agent Street wished all the traders but one to be excluded. He wanted a second Col. Davenport as trader at the Des Moines River Agency.

But Joseph M. Street was not to fight any more battles nor make any more plans for the benefit of his savage wards. Before leaving Prairie du Chien in the fall of 1838 or spring of 1839 ( $\mathrm{I}$ do not know the exact time) he had what was called a "stroke." William B. Street in his article speaks of it as paralysis, but that was evidently a mistake. He was of an apoplectic physique and temperament and the mem. bers of the family now living remember it as apoplexy, followed by a difficulty of speech. He had another attack in November, '39, and during that winter he was confined to his 
room under a physician's care. In the spring he grew much better, but on the afternoon of May 5, 1840, while rising from his chair to get a glass of water from the mantel shelf he fell to the floor dead. Mr. A. W. Street describes his death as follows:

On the day of his death and for sometime before, father was much better, and Uncle Alexander (Dr. Alex. Posey) and all were sanguine of his recovery. It was beautiful weather and that morning he had met the Indians in Council, tho' the interview was brief and personal as I remember.*

I had been with father since dinner-this was the middle of the afternoon-and had roasted him an apple before the open fire in his room. He had eaten the apple and I had brought him a glass of water. Uncle Alexander was writing in the next room where he could see father as be eat in his chair by the window. After giving father the glass of water and waiting till be drank, I walked through the dining room into the garden, but had only reached the stile when the negro boy who was in the room when I left ran after me calling "old master is dying." I ran back to the house and saw father lying on his back before the fire. There were several around him rubbing his arms and legs and applying remedies, but he was dead.

Although there is scarcely an Indian treaty in which the families of agents, sub-agents, or interpreters are not granted lands or money or both, there is but one in which the name of Street is mentioned as a beneficiary, and that is the Sac and Fox treaty of 1842 . The Indians voluntarily requested the United States government to grant to Mrs. Street the land upon which Agent Street and their former chief Wapello were buried.

It is not necessary for me to give a summary of Mr. Street's character and the good that he did. His son William has done this much better than I could in his article for The Annals, July, 1895. My chief object has been to give as faithful a picture as my material would allow, of his work for the Sacs and Foxes.

*There is in Mr. Street's Correspondence a letter to the Commissioner of Iudian Affairs dictated on this day, giving an account of the Council. 
Copyright of Annals of Iowa is the property of State of Iowa, by \& through the State Historical Society of Iowa and its content may not be copied or emailed to multiple sites or posted to a listserv without the copyright holder's express written permission. However, users may print, download, or email articles for individual use. 